\title{
PENAMPILAN REPRODUKSI TERNAK SAPI POTONG DI KECAMATAN BINTAUNA KABUPATEN BOLAANG MONGONDOW UTARA
}

\author{
Aikal Pohontu, Agustinus Lomboan*, Jantje F. Paath, Siane C. Rimbing \\ Fakultas Peternakan Universitas Sam Ratulangi Manado 95115
}

\begin{abstract}
ABSTRAK
Penelitian ini bertujuan untuk mengetahui keadaan reproduksi ternak sapi potong di Kecamatan Bintauna Kabupaten Bolaang Mongondow Utara, karena hal ini sangat menentukan produktivitas ternak terutama dalam peningkatan populasi serta adanya ketersediaan daging. Materi yang digunakan dalam penelitian ini adalah ternak sapi potong milik petani peternak yang diambil secara sampel. Pemilihan sampel desa ditentukan secara senganja (purposive) dengan pertimbangan desa yang memiliki populasi ternak terbanyak yaitu desa Pimpi, desa Kopi, dan kelurahan Bintauna. Pemilihan responden menggunakan metode random sampling yaitu mengambil 10 peternak dari masingmasing desa terpilih sehingga mendapatkan total responden sebanyak 30 peternak. Analisis data mengenai variabel yang di teliti menggunakan analisis deskriptif dengan mengacu pada model pengukuran setiap variabel. Hasil penelitian menunjukkan bahwa umur puberitas ternak yaitu $12,03 \pm 4,81$ bulan, service per conception 1,19 conception rate $73 \%$, lama kebuntingan $276,17 \pm 5,22$ hari, dan calving interval $366,17 \pm 5,22$ hari. Berdasarkan hasil penelitian yang dilakukan dapat disimpulkan bahwa penampilan reproduksi ternak sapi potong di kecamatan Bintauna sudah baik.
\end{abstract}

Kata kunci : Penampilan reproduksi, Sapi, Ternak potong,

*Korespondensi (corresponding Author)

Email: agustinuslomboan@yahoo.co.id
ABSTRACT

REPRODUCTIVE

PERFORMANCE OF BEEF CATTLE IN BINTAUNA DISTRICT OF NORTH BOLAANG MONGONDOW

REGENCY. This study was conducted to evaluate the reproduction performance of beef cattle in Bintauna district of North Bolaang Mongondow regency. Reproductive performance was studied to determine the productivity of livestock especially in population increase and availability of meat. This research used samples of farmer as breeder of beef cattle. The selections of village samples were determined purposively by consideration of the villages with the largest population of livestock including the villages of Pimpi, Kopi, and Bintauna. Selection of respondents using random sampling method involved 10 farmers for each selected village, with the total of 30 farmers as respondents. Data of the variables were analyzed using descriptive analysis model. The results showed that the age of puberty animal was $12.03 \pm 4.81$ months, service per conception was 1.19 , conception rate was $73 \%$, pregnancy period was $276 \pm 2.53$ days, and calving interval was $366 \pm 3.21$ days. Based on these results, it can be concluded that the reproduction of beef cattle in Bintauna district of North Bolaang Mongondow regency was categorized into good performance.

Keyword: Reproduction performance, beef cattle, Bintauna district 


\section{PENDAHULUAN}

Salah satu kebijakan pemerintah dalam pembangunan sub-sektor peternakan adalah upaya untuk mencukupi kebutuhan konsumsi daging sebagai sumber protein hewani asal ternak. Daging dapat dihasilkan dari berbagai komoditas ternak (dapat pula dari produk perikanan), baik yang berasal dari ternak besar (ternak sapi, kerbau) ternak kecil (babi, kambing, domba) dan unggas (ayam dan itik ). Khusus untuk ternak sapi, umumnya daging dihasilkan oleh sapi potong seperti : sapi Bali, sapi Madura dan sapi Peranakan Ongole (PO), serta sapi-sapi import.

Masalah ketersediaan daging terutama daging sapi potong, meskipun ketersediaan ternak sapi cukup, namun belum dapat memenuhi permintaan masyarkat terutama di hari-hari besar keagamaan. Ada beberapa faktor sehingga ketersediaan daging sapi belum maksimal diantaraanya adalah masaalah rendahnya produktifitas ternak sapi potong di Indonesia (rendahnya tingkat kelahiran, lambat beranak, jarak beranak panjang, tingkat kematian pedet tinggi dan perbaikan genetik lambat).

Secara nasional, kebutuhan sapi potong untuk memenuhi konsumsi daging sapi di Indonesia setiap tahun selalu meningkat, sejalan dengan bertambahnya jumlah penduduk, peningkatan pendapatan dan kesejahteraan masyarakat serta semakin tingginya tingkat kesadaran masyarakat akan pentingnya protein hewani. Dipihak lain, kemampuan penyediaannya tumbuh lebih rendah dari pada pertumbuhan permintaannya, akibatnya impor bakalan dan daging terus menunjukkan jumlah yang makin meningkat. Untuk mengurangi kesenjangan ini, diperlukan berbagai upaya yang mampu meningkatkan produktivitas, khususnya pada peternakan sapi potong rakyat.

Fenomena ini menjadi tantangan berat bagi para peternak untuk selalu berupaya memenuhinya sehingga pada saat ini banyak muncul kegiatan agribisnis peternakan sapi potong dan kerja (termasuk peternak ternak sapi potong yang ada di Kecamatan Bintauna, Kabupaten Bolaang Mongondow Utara.

Kabupaten Bolaang Mongondow Utara khususnya di Kecamatan Bintauna memiliki sumber daya alam untuk peternakan sapi potong dan kerja, data terakhir tahun 2016 menunjukkan populasi ternak sapi potong dan kerja di kecamatan Bintauna sekitar 2.231 ekor (BPS, 2016). Hal ini memberikan gambaran bahwa daerah ini sangat potensial untuk pengembangan ternak sapi potong terutama untuk memenuhi kebutuhan akan daging asal ternak. Sehubungan dengan adanya 
upaya pengembangan ternak sapi potong ini, maka hal teknis dalam manajemen pemeliharan ternak seperti penanganan reproduksi penting untuk diketahui karena sangat berpengaruh terhadap produktivitas ternak yang dibudidayakan.

Beberapa hal terkait yang sangat mempengaruhi tinggi rendahnya reproduksi ternak diantaranya yaitu: umur puberitas, angka kebuntingan (conception rate); jarak antar kelahiran (calving interval); jarak waktu antara melahirkan sampai bunting kembali (service periode); angka kawin per kebuntingan (service per conception); angka kelahiran (calving rate), serta lama kebuntingan.

Sehubungan dengan pentingnya informasi mengenai hal-hal yang sifatnya teknis dalam sistim reproduksi pada ternak potong ini serta belum tersedianya informasi, maka penelitian ini dilaksanakan guna mengetahui keadaan reproduksi ternak sapi potong di Kecamatan Bintauna Kabupaten Bolaang Mongondow Utara karena hal ini sangat menentukan produktivitas ternak terutama dalam peningkatan populasi serta adanya ketersediaan daging.

\section{MATERI DAN METODE PENELITIAN}

\section{Waktu dan Lokasi Penelitian}

Penelitian ini telah dilaksanakan sejak tanggal 15 Desember 2016 sampai 15 Januari tahun 2017, bertempat di beberapa desa yang ditentukan berdasarkan jumlah pemilikan ternak di Kecamatan Bintauna Kabupaten Bolaang Mongondow Utara.

\section{Materi Penelitian}

Materi yang digunakan dalam penelitian ini adalah sapi potong milik petani peternak yang diambil secara sampel di beberapa wilayah Kecamatan Bintauna Kabupaten Bolaang Monggondow Utara.

\section{Populasi dan Sampel}

1. Populasi

Populasi dalam penelitian ini adalah seluruh ternak sapi yang ada di Kecamatan Bintauna yang tersebar di 11 desa kecamatan Bintauna.

2. Sampel

Pemilihan sampel desa ditentukan secara senganja (purposive) dengan pertimbangan tertentu (Sugiyono, 2010), yaitu desa yang memiliki populasi ternak sapi potong terbanyak yaitu desa Pimpi, desa Kopi, dan Kelurahan Bintauna. Pemilihan responden peternak sapi potong menggunakan metode random sampling karena pengambilan sampel anggota populasi dilakukan secara acak 
tanpa memperhatikan strata yang ada dalam populasi (Sugiyono, 2010), yaitu mengambil 10 peternak dari masing-masing desa terpilih sehingga mendapatkan total responden sebanyak 30 peternak, untuk sampel ternak yang akan diteliti yaitu ternak sapi potong yang dimiliki oleh 30 peternak tersebut dengan jumlah ternak sapi 293 ekor.

\section{Metode Penelitian dan Pengumpulan}

\section{Data}

Metode penelitian yang digunakan dalam penelitian ini adalah metode survey dengan pengumpulan data primer dan sekunder. Data primer diperoleh dari hasil wawancara (berpedoman pada daftar pertanyaan/kuisioner yang telah disiapkan) dengan sejumlah peternak yang memiliki sapi potong (induk) dengan jumlah pemilikan minimal 5 ekor sapi. Sedangkan data sekunder diperoleh dari berbagai instansi terkait dengan penelitian ini seperti dinas peternakan, monografi kecamatan, kantor statistik dan lain-lain.

\section{Variabel yang di Teliti}

Variabel yang diamati pada ternak sapi potong di kecamatan Bintauna kabupaten Bolaang Mongondow Utara..

1. Umur puberitas
Umur saat dimana ternak sapi potong betina sistem reproduksinya mulai berfungsi (bulan).

2. Service per Conception (S/C)

Service per conception (S/C) adalah jumlah ternak yang kawin yang diperlukan untuk menghasilkan kebuntingan seekor sapi.

3. Conception Rate (CR)

Conception rate (CR) adalah jumlah induk yang positif bunting dibagi jumlah ternak betina yang dikawinkan dikali $100 \%$.

4. Lama kebuntingan

Lama kebuntingan dimulai dengan pembuahan dan berakhir dengan kelahiran anak yang hidup (hari).

5. Calving Interval (CI)

Calving interval (CI) adalah selang waktu dari beranak sampai beranak berikutnya (hari).

\section{Analisis Data}

Analisis data mengenai variabel yang di teliti menggunakan analisis deskriptif dengan mengacu pada model sebagai berikut :

\section{Umur pubertas}

Umur puberitas dihitung berdasarkan umur saat dimana ternak sapi potong betina sistem 
reproduksinya mulai berfungsi

HASIL DAN PEMBAHASAN

(Toelihere, 1995).

2. Service per Conception (S/C)

Perhitungan nilai S/C menurut Hafez (2000) yaitu dengan menggunakan rumus sebagai berikut :

$$
\mathrm{S} / \mathrm{C}=\frac{\text { Jumlah perkawinan }}{\text { Jumlah betina bunting }}
$$

3. Conception Rate (CR)

Perhitungan nilai CR menurut Jaenudeen dan Hafez (2000) yaitu dengan menggunakan rumus sebagai berikut :

Conception Rate $(\%)=$ $\frac{\text { Jumlah betina bunting yang kawin pertama }}{\text { Jumlah seluruh betina yang kawin }} \mathrm{x}$ $100 \%$

\section{Lama kebuntingan}

Lama kebuntingan dimulai dengan pembuahan dan berakhir dengan kelahiran anak yang hidup (Toelihere, 1995).

\section{Calving Interval (CI)}

Perhitungan nilai $\mathrm{CR}$ menurut Ball dan Peters (2004) yaitu dengan menggunakan rumus sebagai berikut :

Calving Interval $($ bulan $)=$ kelahiran ke-i kelahiran ke (i-1)

Calving Interval $($ hari $)=$ periode kebuntingan + days open

\section{Penampilan reproduksi ternak sapi potong}

\section{Umur puberitas}

Umur puberitas adalah umur ternak secara fisik dan fisiologis siap untuk melakukan perkawinan dan berkembang biak. Analisis data mengenai umur puberitas dalam penelitian ini menggunakan asumsi dasar Interval Kelas dengan melihat skala umur 9 sampai 20 bulan. Umur puberitas ternak yang ada di kecamatan Bintauna disajikan dalam Tabel 1.

Hasil penelitian menunjukkan bahwa umur puberitas sapi potong di kecamatan Bintauna berada pada interval 920 bulan dengan persentase nilai yang berbeda-beda. Interval 9-11 bulan paling banyak terjadinya puberitas dengan persentase 54,55\%, sedangkan pada interval 18-20 bulan paling sedikit terjadinya puberitas atau masa awal birahi ternak. Namun demikian secara keseluruhan rataan umur puberitas adalah 12,03 bulan dengan standar deviasi adalah 2,55 , yang berarti bahwa rata-rata puberitas berada pada kisaran 9,48-14,58 bulan. 
Tabel 1. Distribusi Ternak Sapi Potong Berdasarkan Umur Puberitas

\begin{tabular}{cccccc}
\hline \multirow{2}{*}{ No } & \multicolumn{2}{c}{ Umur puberitas (bulan) } & Jumlah & $\begin{array}{c}\text { Persentase } \\
\text { ternak }\end{array}$ & $\begin{array}{c}\text { Rataan umur } \\
\text { puberitas (bulan) }\end{array}$ \\
\hline 1 & $9-11$ & 10 & 42 & 54,55 & \\
2 & $12-14$ & 13 & 20 & 25,97 & $12,03 \pm 2,55$ \\
3 & $15-17$ & 16 & 13 & 16,88 & \\
4 & $18-20$ & 19 & 2 & 2,60 & \\
\hline & Total & & $\mathbf{7 7}$ & $\mathbf{1 0 0}$ & \\
\hline
\end{tabular}

Sumber : Hasil olahan data primer (2017)

Pencapaian puberitas setiap ternak menunjukkan hasil yang tidak seragam, namun secara umum pencapaian umur puberitas atau dewasa kelamin ternak sapi potong dalam kategori baik. Hal ini disebabkan oleh kecamatan Sangkub yang ada di kabupaten Bolaang Mongondow Utara memiliki suhu yang berada pada kisaran 25-27 $\quad{ }^{\circ} \mathrm{C}$ dengan tingkat kelembaban udara $65-90 \%$ dan intensitas curah hujan yang berada pada rata-rata 140,11 $\mathrm{mm}^{3}$ perbulan (BPS, 2016), maka dari itu akan menghasilkan kualitas pakan yang baik pula, serta didukung oleh penerapan sistem pemeliharaan yang sudah dalam bentuk semi intensif.

Iklim dan kondisi lingkungan sangat berpengaruh terhadap ketersediaan mineral dalam pakan hijauan, pada daerah yang kering dan curah hujannya rendah dapat menyebabkan kandungan mineral dalam pakan ternak rendah dan pada musim kemarau kandungan mineral dalam pakan lebih rendah dibandingkan pada musim hujan, jika pakan tersebut defisiensi mineral maka dapat menyebabkan gangguan pada pencapaian umur pubertas (Murni et al., 2015). Hartatik et al. (2009) menambahkan bahwa kualitas pakan yang kurang bagus dan jumlah yang kurang dapat mengganggu proses reproduksi ternak sehingga selain penundaan umur kawin pertama, hal ini juga berakibat pada umur pertama beranak yang dipengaruhi oleh ketepatan deteksi estrus dan keberhasilan perkawinan yang ditunjukkan oleh nilai service per conception.

\section{Service per Conception (S/C)}

Service per Conception (S/C) merupakan jumlah perkawinan yang dibutuhkan oleh ternak betina sampai terjadinya kebuntingan. Menurut Nuryadi dan Wahjuningsih (2011) bahwa kisaran normal nilai S/C adalah 1,6-2,0. S/C dalam penelitian ini diukur berdasarkan perkawinan secara alami atau kawin alam.

Hasil penelitian menunjukkan bahwa rata-rata service per conception di lokasi penelitian adalah 1,19, yang berarti 
bahwa untuk ternak sapi potong di kecamatan Bintauna yang dikawinkan dan terjadinya kebuntingan membutuhkan S/C 1,19 kali atau untuk memperoleh kebuntingan 77 ekor betina diperlukan layanan perkawinan sebanyak 92 kali. Nilai S/C dilokasi penelitian lebih rendah dibandingkan dengan hasil penelitian Winarti dan Supriyadi (2010) di Yogyakarta yaitu S/C 2,68 kali dan penelitian Kasehung et al., (2016) di Kabupaten Minahasa yaitu S/C 1,44 kali.

Hasil penelitian ini menunjukkan bahwa semakin rendah nilai $\mathrm{S} / \mathrm{C}$ maka semakin tinggi kesuburan ternak tersebut, yang berarti bahwa S/C ternak sapi potong di kecamatan Bintauna sudah sangat baik. Hal tersebut selain disebabkan oleh kualitas pejantan yang baik dalam perkawinan, rendahnya nilai $\mathrm{S} / \mathrm{C}$ di lokasi penelitian terjadi akibat adanya perbedaan lingkungan dan menunjukkan adanya upaya perbaikan serta peningkatan manajemen ketika ternak sapi mengalami birahi pertama dan umur yang tepat untuk perkawinan yang diberikan, serta peternak di lokasi penelitian ini cukup mampu dalam mendeteksi siklus birahi ternak dengan tepat. Tinggi rendahnya nilai S/C dapat dipengaruhi oleh beberapa faktor antara lain keterampilan inseminator, waktu dalam melakukan inseminasi buatan dan pengetahuan peternak dalam mendeteksi birahi (Siagarini et al., 2015). Iswoyo dan
Widiyaningrum (2008) juga menambahkan, penyebab tingginya angka S/C umumnya disebabkan : (1) peternak terlambat mendeteksi saat birahi atau terlambat melaporkan birahi sapinya kepada inseminator, (2) adanya kelainan pada alat reproduksi induk sapi, (3) inseminator kurang terampil, (4) fasilitas pelayanan inseminasi yang terbatas, dan (5) kurang lancarnya transportasi.

\section{Conception Rate}

Conception Rate adalah besarnya persentase angka ternak betina yang bunting pada saat kawin pertama dari sejumlah ternak yang dikawinkan.

Hasil penelitian di lokasi menunjukkan bahwa dari 77 ternak yang dikawinkan, 56 ternak mengalami konsepsi atau bunting pada perkawinan pertama dengan nilai Conception Rate (CR) yaitu 73\%. Besarnya nilai CR ini juga disebabkan oleh kualitas pejantan yang baik yang digunakan dalam perkawinan, upaya peningkatan manajemen dalam pendeteksian birahi dengan melihat tingkah laku ternak yaitu, menunjukkan nafsu makan berkurang, tingkah laku gelisah, dan sering keluar lendir, bengkak, merah, basah, serta ketepatan perkawinan yang dilakukan. Tingginya nilai CR di lokasi penelitian juga ditunjukkan oleh rendahnya angka S/C yang berada di bawah 1,6, hal tersebut tidak lepas dari pemberian pakan yang 
berkualitas oleh peternak setiap hari pada ternaknya. Menurut Montiel dan Ahuja (2005) bahwa faktor pakan merupakan faktor paling utama untuk penampilan reproduksi, khususnya pada sapi yang sangat tergantung pada hijauan untuk memenuhi gizinya, sehingga hal ini umumnya akan menyebabkan terjadinya hipofungsi ovarium (tidak adanya aktivitas ovarium) dan sapi tidak menunjukkan tanda-tanda berahi. Demikian pula menurut Kasim et al. (2010) bahwa pada sapi induk yang mendapat makanan kurang (kuantitas maupun kualitas) menyebabkan pada gangguan-gangguan pada tanda-tanda berahi dan menurunnya fertilitas sapi induk.

\section{Lama Kebuntingan}

Lama kebuntingan merupakan periode kebuntingan ternak yang dimulai dengan pembuahan dan berakhir dengan kelahiran pedet yang hidup. Lama kebuntingan ternak sapi potong di kecamatan Bintauna disajikan dalam Tabel 2.

Tabel 2 menunjukkan bahwa lama kebuntingan ternak sapi potong dilokasi penelitian berada pada kisaran 270-285 hari, sebagian besar atau $80,55 \%$ ternak mengalami kebuntingan selama 275 hari. Secara keseluruhan rataan lama kebuntingan ternak yaitu 276,17 hari dengan nilai standar deviasi $\pm 3,00$, yang berarti bahwa rataan lama kebuntingan ternak di kecamatan Bintauna berada pada kisaran 273,17-279,17 hari. Hal ini menunjukkan keadaan reproduksi ternak yang normal yaitu 276,17 hari, dimana telah dilaporkan dari beberapa penelitian bahwa lama kebuntingan ternak sapi bali maupun ongole tidak berbeda secara signifikan. Menurut Saladin (1993), lama

Tabel 2. Distribusi Ternak Sapi Potong Berdasasrkan Lama Kebuntingan

\begin{tabular}{ccccc}
\hline No & $\begin{array}{c}\text { Lama kebuntingan } \\
\text { (hari) }\end{array}$ & Jumlah ternak & Persentase (\%) & $\begin{array}{c}\text { Rataan lama } \\
\text { kebuntingan } \\
\text { (hari) }\end{array}$ \\
\hline 1 & 270 & 1 & 1,29 & \\
2 & 275 & 62 & 80,55 & \\
3 & 277 & 1 & 1,29 & 276,17 \\
4 & 278 & 1 & 1,29 & \\
5 & 280 & 6 & 7,79 & \\
6 & 285 & 6 & 7,79 & $\mathbf{S D} \pm \mathbf{3 , 0 0}$ \\
\hline
\end{tabular}

Sumber : Hasil olahan data primer (2017) 
bunting pada ternak sapi berkisar antara 270-290 hari, Devendra et al. (1973), lama kebuntingan pada ternak sapi bali adalah kisaran 276-295 hari, sedangkan menurut penelitian Prasojo (2010) adalah berkisar antara 278,7 sampai 290,1 hari. Untuk ternak jenis peranakan ongole, menurut Wibowo et al. (2014) adalah berkisar antara 279,63 sampai 284,59 hari.

Menurut Iskandar (2011) bahwa penyebab lama kebuntingan ternak dipengaruhi oleh bangsa sapi, jenis kelamin dan jumlah anak yang dikandung, umur induk, musim, dan letak geografis. Namun demikian, dalam penelitian Prasojo et al. (2010) bahwa dari jumlah 799 kelahiran ternyata lama kebuntingan pada sapi Bali antara pedet jantan dan pedet betina tidak menunjukkan perbedaan yang signifikan. Lama kebuntingan pada induk yang mengandung pedet jantan adalah $284,4 \pm 5,7$ hari, dan induk yang mengandung pedet betina hampir sama yaitu $283,9 \pm 5,6$ hari.
Sedangkan untuk bangsa sapi peranakan ongole (PO) menurut Kasehung et al. (2016) lama kebuntingan pada induk berada pada kisaran 284-291 hari.

\section{Calving Interval (CI)}

Calving Interval (CI) adalah jangka waktu yang dihitung dari tanggal seekor sapi potong beranak sampai beranak kembali, atau jarak beranak dari anak satu keanak berikutnya. Nuryadi dan Wahjuningsih (2011) menyatakan bahwa CI ditentukan oleh lama bunting dan lama kosong, sehingga semakin panjang masa kosong (DO) maka nilai CI juga akan semakin tinggi. Adapun nilai CI ternak sapi potong dilokasi penelitian disajikan dalam Tabel 3.

Tabel 3 menunjukkan bahwa Calving Interval (CI) ternak dilokasi penelitian memiliki nilai yang beragam yaitu berada antara 360-375 hari. Sebagian besar atau $80,55 \%$ ternak mengalami

Tabel 3. Distribusi Ternak Sapi Potong Berdasarkan Calving Interval

\begin{tabular}{cccc}
\hline $\begin{array}{c}\text { Calving Interval } \\
\text { (CI) }\end{array}$ & Jumlah ternak & Persentase (\%) & Rataan CI (hari) \\
\hline 360 & 1 & 1,29 & \\
365 & 62 & 80,55 & \\
367 & 1 & 1,29 & 366,17 \\
368 & 1 & 1,29 & \\
370 & 6 & 7,79 & \\
375 & 6 & 7,79 & SD $\pm \mathbf{3 , 0 0}$ \\
\hline
\end{tabular}

Sumber : Hasil olahan data primer (2017) 
mengalami jangka waktu beranak kembali setelah 365 hari. Namun demikian, secara keseluruhan ternak sapi potong dilokasi penelitian memiliki rataan CI 366,17 hari dengan standar deviasi adalah 3,00. Hasil penelitian menunjukkan jarak beranak sampai beranak berikutnya ternak sapi potong di kecamatan Bintauna sudah tergolong baik. Hal ini dapat disebabkan oleh umur puberitas yang ideal, perkawinan yang tepat, serta nilai S/C yang rendah.

Menurut Supriyadi (2010), calving interval sangat dipengaruhi oleh estrus post partum serta besarnya S/C. Keberhasilan perbaikan S/C dan estrus post partum otomatis akan memperpendek calving interval. Untuk memperpendek calving interval juga disarankan untuk tidak menunda perkawinan pascapartum. Hal ini didukung oleh pendapat Rhodes et al. (2003) bahwa estrus pasca partus merupakan hal yang penting pada sapi untuk dapat melahirkan setiap tahun satu ekor anak dengan jarak kelahiran 365 hari. Untuk mencapai hal tersebut, sapi harus dikawinkan paling lambat 83 hari setelah melahirkan dengan asumsi lama kebuntingan 276-295 hari. Siregar (2003) menambahkan, untuk memperpendek jarak beranak dapat dilakukan melalui dua cara yaitu sapi induk harus dikawinkan 60 hari setelah beranak dan jumlah perkawinan (S/C) tidak lebih dari dua kali.

\section{KESIMPULAN}

Berdasarkan hasil penelitian yng dilakukan dapat disimpulkan bahwa penampilan reproduksi ternak sapi potong di kecamatan Bintauna sudah baik yaitu dengan umur puberitas $12,03 \pm 2,55$ bulan, service per conception 1,19, conception rate $73 \%$, lama kebuntingan $276,17 \pm 3,00$ hari, dan calving interval 366,17 $\pm 3,00$ hari.

\section{DAFTAR PUSTAKA}

Badan Pusat Statistik. 2016. Statistik Daerah Kecamatan Bintauna: Badan Pusat Statistik Kabupaten Bolaang Mongondow Utara.

Ball, P.J.H., and A.R. Peters. 2004. Reproduction In Cattle. Third Edition. Blackwell Publishing.Victoria. Australia. De Vries, A. 2006. Determinants of the cost of days open in dairy cattle. Department of Animal Sciences. University of Florida. Gainesville 32611. USA

Devendra, C.T., K.C. Lee, Pathmasingam. 1973. The Productivity of bali cattle in Malaysia. J. Agric 49:183-197.

Hafez, E.S.E., 2000. Reproduction in Farm Animal. 6th Edition. Lea and Febiger. Philadelpia

Hartatik, T., D. A. Mahardika, T. S. M. Widi, dan E. Baliarti. 2009. Karakteristik dan kinerja induk sapi Silangan Limousin -Madura dan Madura di Kabupaten Sumenep dan Pamekasan. Buletin Peternakan. 33 (3) : 143-147. 
Iskandar. 2011. Performan reproduksi sapi po pada dataran rendah dan dataran tinggi di Provinsi Jambi. Jurnal Ilmiah Ilmu-Ilmu Peternakan, 14 (1) : 51-61.

Iswoyo dan P. Widiyaningrum. 2008. Performans reproduksi sapi peranakan Simmental (Psm) hasil inseminasi buatan di Kabupaten Sukoharjo Jawa Tengah. Jurnal Ilmiah Ilmu-ilmu Peternakan. 11(3): 125-133.

Kasehung, J., U. Paputungan, S. Adiani, dan J. Paath. 2016. Performans reproduksi induk sapi lokal Peranakan Ongole yang dikawinkan dengan teknik inseminasi buatan di Kecamatan Tompaso Barat Kabupaten Minahasa. Jurnal Zootek. 36 (1) : 167-173.

Kasim, K., S. Sagaf, A. B. Languha, dan A. D. Malewa. 2010. Analisis produktivitas sapi betina induk di Sulawesi Tengah. J. Agroland 17 (1) : 70-76

Montiel, F., and C. Ahuja. 2005. Body condition and suckling as factors influencing the duration of postpartum anestrus in cattle: A review. Anim. Reprod. Sci. 85 : 1-26.

Murni, R., Yatno dan Nelson. 2015. Pelatihan pembuatan lamtoro mineral blok pada peternak rakyat di Desa Pematang Gajah Kabupaten Muaro Jambi. J. Pengabdian pada Masyarakat. 30 (4) : 49-54.

Nuryadi dan S. Wahjuningsih. 2011. Penampilan reproduksi sapi Peranakan Ongole dan Peranakan Limousin di Kabupaten Malang. J. Ternak Tropikal 12 (1) : 76-81.

Prasojo, G., I. Arifiantini, dan K. Mohamad. 2010. Korelasi antara lama kebuntingan, bobot lahir dan jenis kelamin pedet hasil inseminasi buatan pada Sapi Bali. Jurnal Veteriner. 11 (1) : 41-45.

Rhodes, F.M., S. McDougall, C. R. Burke, G. A. Verkerk, and K. L. Macmillan. 2003. Invited Review: Treatment of cows with an extended postpartum anestrous interval. J. Dairy Sci. 86 (6) : 1876-1884.

Saladin, R. 1993. Teknik Produksi Sapi Potong. Fakultas Peternakan Universitas Andalas, Sumatera Barat.

Siagarini, V. D., N. Isnaini, S. Wahjuningsih. 2015. Service per conception (S/C) dan conception rate (Cr) sapi Peranakan Simmental pada paritas yang berbeda Di Kecamatan Sanankulon Kabupaten Blitar. J. Ilmu-Ilmu Peternakan. 1 (1) : 1-6.

Siregar, S. B. 2003. Peluang dan tantangan peningkatan produksi susu nasional. Wartazoa 13 (2) : 48 -55.

Sugiyono, (2010). Metode Penelitian Kuantitatif, Kualitatif, dan R\&D. Alfabeta. Bandung.

Supriyadi, E. W. 2010. Penampilan reproduksi ternak sapi potong betina Di Daerah Istimewa Yogyakarta. Seminar Nasional Teknologi Peternakan Dan Veteriner. Balai Pengkajian Teknologi Pertanian, Yogyakarta. Hal : 64-67

Toelihere, M. R, 1981. Fisiologi Reproduksi pada Ternak. Angkasa. Bandung

Wibowo, F. C. P., N. Isnaini, dan S. Wahjuningsih. 2014. Performan reproduksi sapi Peranakan Ongole dan sapi Peranakan Limousine di Kecamatan Berbek Kabupaten Nganjuk. Fakultas Peternakan Universitas Brawijaya. Malang.

Winarti, E. dan Supriyadi. 2010. Penampilan Reproduksi Ternak Sapi Potong Betina di Daerah Istimewa 
Yogyakarta. Seminar Nasional Teknologi Peternakan dan Veteriner. Balai Pengkajian Teknologi Pertanian Yogyakarta. Hal : 6467. 